\title{
A tribute to Frederick (Fred) J. Kruger
}

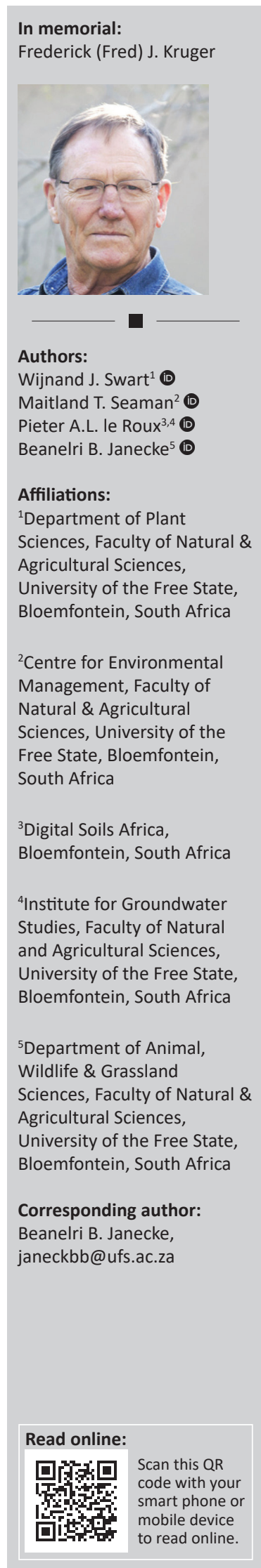

Frederick J. Kruger, passed away in his sleep in May 2017 in Stellenbosch after a short illness. Fred, as he was known to everyone, was highly educated in forest science and ecology and a pioneer of forest hydrology, fynbos ecology and invasive species. Fred was a Member of the Royal Society, and a former director of the South African Forestry Research Institute, and of the CSIR's Division of Forest Science and Technology.

His passing left an indelible mark on forestry and environmental science in South Africa. Fred was an intellectual (although he refused to be called an academic) and uncompromising in his pursuit of answers. He was supportive, understated but provocative, with dignity and integrity and always a twinkle in his eyes. In recent years, he was a major contributor to scholarly literature about the environmental history of South Africa.

He often collaborated in ecological research and was actively involved from 2015 to 2017 in this multidisciplinary research project near Skukuza in the Kruger National Park (published in this special issue) together with colleagues from the University of the Free State. The main concept of the study was the 'brain child' of Fred and Piet le Roux. Fred stimulated the team's thoughts on the interaction between the biosphere and lithosphere and he encouraged us to always focus on the bigger ecological picture. His active involvement in this project led to the discovery of a new species of fungus, which was subsequently described and named after him (Fusarium fredkrugeri Sandoval-Denis, Crous \& W.J. Swart, sp. nov.). His extensive knowledge and experience will be sorely missed by all those people he interacted with over many years.

At the time of his passing, he was an active Research Fellow of the Centre for Environmental Management at the University of the Free State, and was investigating and documenting studies on the role of water in rivers in the catchments of the Kruger National Park.

This is a tribute to honour Dr Fred Kruger, and to show our respect, gratitude and admiration when we remember the huge contribution that he has made to the research published in this special issue.

How to cite this article: Swart, W.J., Seaman, M.T., Le Roux, P.A.L., Janecke, B.B. 2020, 'A tribute to Frederick (Fred) J. Kruger', Koedoe 62(2), a1639. https://doi.org/10.4102/koedoe.v62i2.1639

Copyright: (C) 2020. The Authors. Licensee: AOSIS. This work is licensed under the Creative Commons Attribution License.

Note: Special Issue: Connections between abiotic and biotic components of a granite catena ecosystem in Kruger National Park, sub-edited by Beanelri Janecke and Johan van Tol. 